\title{
Tissue oxygen saturation as an early indicator of delayed lactate clearance after cardiac surgery: a prospective observational study
}

Rüdger Kopp ${ }^{1 *}$, Katja Dommann ${ }^{1}$, Rolf Rossaint ${ }^{2,1}$, Gereon Schälte ${ }^{2}$, Oliver Grottke ${ }^{2}$, Jan Spillner ${ }^{3}$, Steffen Rex ${ }^{4,5}$ and Gernot Marx ${ }^{1,2}$

\begin{abstract}
Background: In this observational study near infrared spectroscopy (NIRS) was evaluated as a non-invasive monitor of impaired tissue oxygenation $\left(\mathrm{StO}_{2}\right)$ after cardiac surgery. $\mathrm{StO}_{2}$, cardiac output, mixed venous oxygen saturation and mean arterial pressure were compared with lactate clearance as established measure for sufficient tissue perfusion and oxygen metabolism.

Methods: Forty patients after cardiac surgery (24 aortocoronary bypass grafting, 5 heart valve, 3 ascending aorta and 8 combined procedures) were monitored until postoperative day 1 with NIRS of the thenar muscle (InSpectra ${ }^{\mathrm{TM}}$ $\mathrm{StO}_{2}$-monitor, Hutchinson Technology), a pulmonary-artery catheter and intermittent blood gas analyses for the assessment of lactate clearance.

Results: $\mathrm{StO}_{2}$ was reduced $4 \mathrm{~h}$ after surgery $(75 \pm 6 \%)$, but recovered at day $1(84 \pm 5 \%)$, while lactate concentration remained increased. Using uni- and multivariate regression analysis, minimum $\mathrm{StO}_{2}(r=0.46, p<0.01)$ and cardiac index $(r=0.40, p<0.05)$ correlated with lactate clearance at day 1 , while minimum mixed venous saturation and mean arterial pressure did not. In a receiver-operating characteristics (ROC) analysis, minimum $\mathrm{StO}_{2}$ (with a threshold of $75 \%$ ) predicted a lactate clearance $<10 \%$ at day 1 with an area under the ROC-curve of 0.83 , a sensitivity of $78 \%$ and a specificity of $88 \%$. In the subgroup with $\mathrm{StO}_{2}<75 \%$, troponin and creatine kinase MB were significantly increased at day 1 .
\end{abstract}

Conclusions: $\mathrm{StO}_{2}$ below $75 \%$ in the first hours after surgery was a better early indicator of persistent impaired lactate clearance at day 1 than cardiac index, mixed venous oxygen saturation or mean arterial pressure.

Keywords: Cardiac Surgical Procedure, Microcirculation, Lactic acid, Haemodynamics, Tissue oxygenation

\section{Background}

After cardiac surgery, haemodynamics and systemic oxygenation are often impaired and clinical guidelines address sufficient tissue perfusion and oxygen metabolism as primary goal of haemodynamic management [1]. Recommended monitoring of therapeutic goals includes direct and indirect parameters of global haemodynamics, such as cardiac index, arterial and central venous blood

\footnotetext{
*Correspondence: rkopp@ukaachen.de

'Department of Intensive Care, University Hospital RWTH Aachen, RWTH

Aachen University, Pauwelsstr. 30, 52074 Aachen, Germany

Full list of author information is available at the end of the article
}

pressure, as well as central $\left(\mathrm{S}_{\mathrm{cv}} \mathrm{O}_{2}\right)$ or mixed venous oxygen saturation $\left(\mathrm{S}_{\mathrm{v}} \mathrm{O}_{2}\right)$. Additionally lactate concentration should be measured as a surrogate parameter of tissue hypoxia. In a prospective observational study immediate as well as delayed hyperlactatemia was associated with increased morbidity and mortality after 325 cardiopulmonary bypass operations [2]. Lindsay et al. demonstrated in a retrospective study that lactate concentration and clearance were associated with mortality, reoperation and morbidity of 1291 patients after cardiac surgery [3]. 
To overcome some limitations of indirectly monitored tissue perfusion and oxygenation near-infrared spectroscopy (NIRS) was developed measuring directly and continuously tissue oxygen saturation $\left(\mathrm{StO}_{2}\right)[4,5]$. In critically ill patients evaluation of $\mathrm{StO}_{2}$ demonstrated for example, that minimum $\mathrm{StO}_{2}$ predicted multiple organ failure after severe trauma patients [6] and after early goal-directed therapy of septic shock, a $\mathrm{StO}_{2}$ value below $78 \%$ was associated with increased mortality at day 28 [7].

Even after major non-cardiac surgery, minimum intraoperative $\mathrm{StO}_{2}$, but not mean $\mathrm{StO}_{2}$, was associated with a composite endpoint of major postoperative complications and mortality in a prospective observational study [8]. For cardiac surgery Uilkema and Groeneveld could demonstrate, that $\mathrm{StO}_{2}$ decreased significantly up to $22 \mathrm{~h}$ after surgery [9]. In 74 adults undergoing cardiac surgery, perioperative reduced $\mathrm{StO}_{2}$ was associated with increased postoperative morbidity 3 and 15 days after surgery [10].

The aim of this study was to evaluate the potential of near-infrared spectroscopy as a direct and early indicator of impaired tissue oxygenation after cardiac surgery. We tested the hypothesis, that $\mathrm{StO}_{2}$ in the first hours after cardiac surgery could predict a late hyperlactatemia and delayed lactate clearance on the first postoperative day.

\section{Methods}

In this prospective observational study, $\mathrm{StO}_{2}$ was measured in 40 patients with elective cardiac surgery using non-invasive $\mathrm{StO}_{2}$-monitoring (InSpectra ${ }^{\mathrm{Ts}} \mathrm{StO}_{2}$, Hutchinson Technology Inc., Hutchinson, Minnesota, USA) in the period from January 2008 to June 2008. The study was approved by the RWTH Aachen University regional research ethics committee (Ref: EK 161/07) and met the Declaration of Helsinki criteria. The patients were included the day before surgery by chance, when written informed consent could be obtained for participation in the study including data publication. The reporting of this study follows the STROBE statement for observational studies [11]. Patient number was assumed from already published observational studies on $\mathrm{StO}_{2}$ [12-14]. Inclusion criteria were surgery for aortocoronary bypass, valve repair or replacement of the ascending aorta as well as a combination of these operations. Exclusion criteria were pregnancy, age younger than 18 years, emergency operation, a moribund status before operation or a contraindication for extended haemodynamic monitoring with a pulmonary artery catheter (PAC). EURO score, age, sex and type of operation were recorded.

\section{Anaesthesia}

Anaesthesia, haemodynamics, fluid management and blood transfusion were managed according to in-house standard. Patients received an oral premedication with $7.5 \mathrm{mg}$ midazolam and anaesthesia was induced with etomidate
$0.1 \mathrm{mg} \cdot \mathrm{kg}^{-1}$, sufentanil $0.5-1.0 \mu \mathrm{g} \cdot \mathrm{kg}^{-1}$ and rocuronium $1 \mathrm{mg} \cdot \mathrm{kg}^{-1}$. Anaesthesia was maintained with sufentanil $1.0 \mu \mathrm{g} \cdot \mathrm{kg}^{-1} \cdot \mathrm{hr}^{-1}$, isoflurane (0.4-1.0 minimum alveolar concentration) and propofol 2-4 $\mathrm{mg} \mathrm{kg}^{-1} \cdot \mathrm{hr}^{-1}$ during cardiopulmonary bypass. Installation of the patients included orotracheal intubation, arterial and central venous catheterization, placement of a PAC via an introducer sheath in the jugular vein, and transurethral catheterization. Parameters of systemic haemodynamics including cardiac index, lactate concentration, base deficit and $\mathrm{S}_{\mathrm{v}} \mathrm{O}_{2}$ were measured. The $\mathrm{StO}_{2}$ sensor was placed on the thenar muscle of the right hand in a position, which ensured an adequate total haemoglobin index (THI) of more than 5.0 according to the recommendation of the manufacturer. A system check was performed before application of the sensor. At the different time points, a THI greater than 5.0 was confirmed before recording of $\mathrm{StO}_{2}$ to avoid artefacts. To measure tissue oxygen saturation near-infrared light $(680-800 \mathrm{~nm})$ is emitted into the thenar tissue with a depth of about $15 \mathrm{~mm}$. In the light that is reflected from the tissue, the percentage of oxygenated haemoglobin is calculated by using the different absorption spectra of oxygenated and deoxygenated haemoglobin.

\section{Intensive Care Unit}

At end of surgery, patients were transferred to the Intensive Care Unit (ICU) and analgosedation was maintained with sufentanil $0.5-1.0 \mu \mathrm{g} \cdot \mathrm{kg}^{-1} \cdot \mathrm{hr}^{-1}$ and propofol $1-3 \mathrm{mg}$. $\mathrm{kg}^{-1} \cdot \mathrm{hr}^{-1}$. Haemodynamics were stabilized with intravenous fluid administration, noradrenaline as vasopressor and adrenaline for inotropic support depending on $\mathrm{S}_{\mathrm{v}} \mathrm{O}_{2}$, cardiac output, blood pressure and clinical assessment according to clinical guidelines [1]. After respiratory and haemodynamic stability as well as normothermia had been achieved, analgosedation was terminated to extubate patients.

\section{Data acquisition}

Complete data were captured after induction of anaesthesia ( $\mathrm{T}-1)$, at the end of surgery ( $\mathrm{T} 0), 1 \mathrm{~h}(\mathrm{~T} 1), 4 \mathrm{~h}$ ( $\mathrm{T}$ 4 ) and the next morning after surgery ( $\mathrm{T} \mathrm{d} 1$ ). At these time points pulmonary capillary wedge pressure, cardiac index and $\mathrm{S}_{\mathrm{v}} \mathrm{O}_{2}$ were measured and actual values of continuously measured haemodynamic parameters $\left(\mathrm{StO}_{2}\right.$, heart rate, arterial, pulmonary arterial, central venous pressure) were prospective recorded. In addition, arterial blood gas analyses were performed for the assessment of lactate concentration, base deficit, $\mathrm{pH}$, haemoglobin concentration and oxygen saturation $\left(\mathrm{S}_{\mathrm{a}} \mathrm{O}_{2}\right)$. Lactate clearance was calculated as previously published [15]: (lactate $\mathrm{T}_{\mathrm{T} 0}-$ lactate $\left._{\mathrm{Tx}}\right) \cdot$ lactate $_{\mathrm{T} 0}^{-1} \cdot 100 \%$.

Laboratory values, fluid balance and application of vasoactive drugs were recorded according to local standard. Aortic cross-clamping time, cardiopulmonary bypass time, 
length of ICU stay, duration of mechanical ventilation and SOFA score were registered from patient data.

\section{Statistical analysis}

Mean and standard deviation (SD) were calculated. After confirmation of normal distribution with the KolmogorovSmirnov test, differences between time points were tested using ANOVA. When repeated measures ANOVA detected statistical significance, it was followed by a Tukey multiple comparisons post-test for dependent samples to correct for multiple measurements. Statistical significance between subgroups was tested with unpaired $t$ test after confirmation of normal distribution.

Univariate and multiple regression analysis were performed to assess the correlation between cardiac index (CI), $\mathrm{S}_{\mathrm{v}} \mathrm{O}_{2}$, mean arterial pressure (MAP) and lactate clearance. InStat Statistical Software version 3.06 (GraphPad, San Diego, USA) was used for statistical analysis and a $p$-value $<0.05$ was considered significant. Sigma Plot 11.0 Software (Systat Software, Inc., San José, USA) was used for the assessment of receiver operating characteristic (ROC) curves and the definition of an optimum threshold by calculating the maximum Youden index $(J$ = Sensitivity + Specifity-1) .

\section{Results}

In this observational study, 40 patients after cardiac surgery (30 male and 10 female) were included. Complete data including outcome were received from all patients. Demographic data are presented in Table 1 including mean Euro-Score and type of operation.

After ICU admission, $\mathrm{StO}_{2}$ was significantly reduced ( $\mathrm{T} 1$ and $\mathrm{T} 4$ ) and recovered at day 1 ( $\mathrm{T} \mathrm{d} 1$ ), whereas other parameters of tissue oxygen delivery and consumption including lactate concentration and base deficit demonstrated significantly higher values at $\mathrm{T} \mathrm{d} 1$ compared to $\mathrm{T}-1$ (Table 2). After surgery, cardiac index declined at $\mathrm{T}$ 1 and $\mathrm{T} 4$ followed by a recovery at $\mathrm{T} \mathrm{d} 1 . \mathrm{S}_{\mathrm{v}} \mathrm{O}_{2}$ was persistently reduced after $\mathrm{T}-1$. Table 2 summarizes haemodynamic data and the results of the blood gas analysis.

In a $\mathrm{ROC}$-analysis, $\mathrm{StO}_{2}$, cardiac index, mean arterial pressure and $\mathrm{S}_{\mathrm{v}} \mathrm{O}_{2}$ at the various time points were analysed with respect to their ability to predict a lactate clearance of $<10 \%$ at $\mathrm{T} \mathrm{d} 1$. All these parameters demonstrated an area under the curve (AUC) only close to 0.5 (Fig. 1). An additional ROC-analysis showed that the minimum values of $\mathrm{StO}_{2}$, cardiac index, mean arterial pressure and $\mathrm{S}_{\mathrm{v}} \mathrm{O}_{2}$ at the pre-defined time points predicted a lactate clearance of $<10 \%$ at T d1 with an AUC of 0.83 for $\mathrm{StO}_{2}, 0.64$ for cardiac index, 0.47 for mean arterial pressure and 0.56 for $\mathrm{S}_{\mathrm{v}} \mathrm{O}_{2}$ (Fig. 2). A minimum $\mathrm{StO}_{2}<75 \%$ was identified as the optimum threshold for a lactate clearance $<10 \%$ with a sensitivity of $78 \%$ and a specificity of $88 \%$. A minimum $\mathrm{StO}_{2}<75 \%$ was
Table 1 Base line data of patients

\begin{tabular}{llccr}
\hline & & Mean (SD) & Median & Range \\
\hline Age & years & $68.7(8.0)$ & 70 & $45-85$ \\
Male & $\mathrm{n}$ & 30 & & \\
Female & & 10 & & \\
Euroscore & value & $6(4)$ & 7 & $0-12$ \\
& $\%$ & $10.4(10.2)$ & 6.1 & $0.9-35.2$ \\
Type of operation & & Number & $\%$ & \\
Isolated Aortocoronary & $\mathrm{n}$ & 24 & 60.0 & \\
bypass & & & & \\
$\quad$ off pump & & 7 & 17.5 & \\
$\quad$ Combined aortocoronary & $\mathrm{n}$ & 7 & 17.5 & \\
bypass & & & & \\
Other (including combination) & $\mathrm{n}$ & 16 & 40.0 & \\
$\quad$ Aortic valve & & 8 & 20.0 & \\
$\quad$ Mitral valve & & 3 & 7.5 & \\
$\quad$ Aortic and mitral valve & & 2 & 5.0 & \\
$\quad$ Ascending aorta & & 3 & 7.5 & \\
$\quad$ Cardiopulmonary bypass & $\mathrm{n}$ & 33 & 82.5 & \\
\hline
\end{tabular}

observed in 26 patients (65\% of all patients), predominantly at $\mathrm{T} 1(\mathrm{n}=17)$ and $\mathrm{T} 4(\mathrm{n}=18)$ but only two times at $\mathrm{T} 0$ and $\mathrm{T} \mathrm{d} 1$. Of note, for patients with minimum $\mathrm{StO}_{2}<75 \%$ or $\geq 75 \%$, haemodynamic management was not different including therapy with vasopressors, inotropic support, fluid intake and blood transfusion. Analysing minimum $\mathrm{StO}_{2}$ and Lactate Clearance at $\mathrm{T}$ d1 separately for subgroups with off-pump surgery and surgery with $\mathrm{CPB}$ demonstrated no significant differences (Minimum $\mathrm{StO}_{2}$ off-pump $71 \pm 3 \%$ versus $\mathrm{CPB}$-surgery $74 \pm 6 \%$ and lactate clearance at $\mathrm{T}$ d1 off-pump $-56 \pm$ $68 \%$ versus CPB-surgery $-49 \pm 76 \%$ ).

Univariate and multiple regression analysis showed significant correlations between minimum values of $\mathrm{StO}_{2}$ and cardiac index vs. lactate clearance, but not for minimum values of $\mathrm{S}_{\mathrm{v}} \mathrm{O}_{2}$ and mean arterial pressure (Table 3). After identification of 13 patients with a maximum lactate concentration higher than $2.0 \mathrm{mmol} \cdot \mathrm{l}^{-1}$, univariate analysis of this subgroup demonstrated also a significant correlation of minimum $\mathrm{StO}_{2}$ with lactate clearance at $\mathrm{T} \mathrm{d} 1(r=0.63, p<0.05)$. Patients with a minimum $\mathrm{StO}_{2} \geq 75$ \% demonstrated a significantly better recovery of lactate clearance at day 1 compared to patients with a minimum $\mathrm{StO}_{2}<75 \%$ (Fig. 3). Only the subgroup with a minimum $\mathrm{StO}_{2}<75 \%$ demonstrated a significant increase in creatine kinase $\mathrm{MB}$ and troponin $\mathrm{T}$ from $\mathrm{T} 0$ to $\mathrm{T} \mathrm{d} 1$ (Table 4). With respect to the SOFA-scores at $\mathrm{T}$ d1, the two subgroups did not differ (Table 5).

\section{Discussion}

In this observational study, near-infrared spectroscopy of peripheral thenar muscle observed impairment and 
Table 2 Haemodynamics, gas exchange and metabolic state of patients

\begin{tabular}{|c|c|c|c|c|c|}
\hline & $T-1$ & T0 & T 1 & T4 & Td1 \\
\hline & After induction of anaesthesia & After surgery & 1 hour after surgery & 4 hours after surgery & Day 1 \\
\hline $\mathrm{StO}_{2}(\%)$ & $85(4)^{*}$ & $86(6)^{* *}$ & $76(7)^{* * * * * * * *}$ & $75(6)^{* * * * * * * * *}$ & $84(5)^{* * * * * * * *}$ \\
\hline $\mathrm{TH}$ & $13.5(1.8)^{*}$ & $13.5(2.0)^{* *}$ & $12.6(1.6)^{* * * *}$ & $12.4(1.5)^{*, * *}$ & $12.6(2.1)^{* * * *}$ \\
\hline Heart rate $\left(\mathrm{min}^{-1}\right)$ & $64(12)^{*}$ & $87(9)^{*}$ & $88(8)^{*}$ & $91(8)^{*}$ & $91(9)^{*}$ \\
\hline MAP $(\mathrm{mmHg})$ & $84(15)$ & $80(12)$ & $81(12)$ & $77(11)$ & $82(15)$ \\
\hline MPAP (mmHg) & $24(8)$ & $25(11)$ & $26(6)^{* * *}$ & $27(7)^{* * * *}$ & $22(7)^{* * * * * * * *}$ \\
\hline CVP $(\mathrm{mmHg})$ & $12(4)^{*}$ & $12(5)^{* *}$ & $12(3)$ & $12(4)^{* * * *}$ & $9(4)^{*, * * * * * * *}$ \\
\hline PCWP (mmHg) & $16(6)^{*}$ & $13(5)^{* *}$ & $11(4)^{*, * *, * * *}$ & $11(4)^{*, * *, * * * *}$ & $8(5)^{*, * *, * * *, * * * *}$ \\
\hline $\mathrm{Cl}\left(\mathrm{L} \mathrm{min}^{-1} \mathrm{~m}^{-2}\right)$ & $2.0(0.4)^{*}$ & $2.5(0.7)^{*, * *}$ & $2.1(0.7)^{* * * * * *}$ & $2.4(0.6)^{*}$ & $2.7(0.8)^{*, * * *}$ \\
\hline Body temperature $\left({ }^{\circ} \mathrm{C}\right)$ & $36.0(0.5)^{*}$ & $36.0(0.8)^{* *}$ & $35.4(0.9)^{*, * * * * * *}$ & $36.3(0.9)^{* * * * * * * *}$ & $37.2(0.5)^{*, * * * * * *, * * * * *}$ \\
\hline $\mathrm{FiO}_{2}$ & $0.9(0.2)^{*}$ & $1.0(0.0)^{* *}$ & $0.6(0.1)^{*, * *, * * * *}$ & $0.4(0.1)^{*, * * *, * * *}$ & $0.3(0.1)^{*, * * * * * * *}$ \\
\hline Haemoglobin $\left(\mathrm{g} \cdot \mathrm{dl}^{-1}\right)$ & $12.8(1.5)^{*}$ & $9.8(1.5)^{*}$ & $9.3(1.5)^{* * * *}$ & $10.0(1.1)^{*}$ & $10.5(1.2)^{* * * *}$ \\
\hline $\mathrm{S}_{\mathrm{a}} \mathrm{O}_{2}(\%)$ & $100(0)^{*}$ & $100(0)^{* *}$ & $99(1)^{* * *}$ & $98(3)^{*, * *, * * *}$ & $97(2)^{*, * *, * * *}$ \\
\hline $\mathrm{P}_{\mathrm{a}} \mathrm{O}_{2}(\mathrm{mmHg})$ & $354(128)^{*}$ & $368(121)^{* *}$ & $210(88)^{*, * *, * * *}$ & $127(47) * * * * * * *$ & $103(31)^{* * * * * * * *}$ \\
\hline Arterial pH & $7.42(0.05)^{*}$ & $7.38(0.05)^{*, * *}$ & $7.39(0.08)^{* * *}$ & $7.33(0.07)^{*, * * * * * *, * * * *}$ & $7.37(0.05)^{*, * * * *}$ \\
\hline Base Deficit & $0.3(2.5)^{*}$ & $-2.0(3.9)^{*}$ & $-2.0(2.6)^{*}$ & $-2.3(2.9)^{*}$ & $-2.3(2.5)^{*}$ \\
\hline $\mathrm{S}_{\mathrm{V}} \mathrm{O}_{2}(\%)$ & $81(8)^{*}$ & $72(9)^{*}$ & $71(8)^{*}$ & $67(9)^{*}$ & $67(7)^{*}$ \\
\hline Lactate $\left(\mathrm{mmol} \cdot \mathrm{L}^{-1}\right)$ & $0.58(0.21)^{*}$ & $1.1(0.84)^{*, * *}$ & $1.39(1.24)^{*}$ & $1.69(1.61)^{*, * *}$ & $1.46(0.77)^{*}$ \\
\hline Lactate clearance (\%) & $38(24)^{*}$ & $0(0)^{*,+}$ & $-26(49)^{*}$ & $-55(112)^{*, * *}$ & $-51(74)^{* * * *}$ \\
\hline Norepinephrine $\left(\mu \mathrm{g} \mathrm{kg}{ }^{-1} \min ^{-1}\right)$ & $0.00(0.00)^{*}$ & $0.03(0.06)^{*}$ & $0.05(0.08)^{* * * * * *}$ & $0.05(0.09)^{* * * * * * *}$ & $0.02(0.07)^{* * * * * * * *}$ \\
\hline Epinephrine $\left(\mu \mathrm{g} \mathrm{kg}{ }^{-1} \min ^{-1}\right)$ & $0.00(0.00)^{*}$ & $0.01(0.02)$ & $0.01(0.03)^{*}$ & $0.01(0.03)$ & $0.00(0.01)$ \\
\hline
\end{tabular}

$\mathrm{StO}_{2}$, tissue oxygen saturation, $\mathrm{TH}$ l total haemoglobin index, MAP mean arterial pressure, MPAP mean pulmonary artery pressure, CVP central venous pressure, $P C W P$ pulmonary capillary wedge pressure, $\mathrm{Cl}$ Cardiac index, $\mathrm{FiO}_{2}$ fraction of inspired oxygen, $\mathrm{S}_{a} \mathrm{O} 2$ arterial oxygen saturation, $\mathrm{P}_{a} \mathrm{O}_{2}$ arterial partial oxygen pressure, $\mathrm{S}_{v} \mathrm{O} 2$ mixed venous oxygen saturation

Data is presented as mean (SD) and $p<0.05$ was considered significant between time points: * T -1 vs. T 0-T d1, ** T 0 vs. T1-T d1, *** T 1 vs. T 4-T d1, ${ }^{* * * *} \mathrm{~T} 4$ vs. $\mathrm{T}$ d1

recovery of tissue oxygenation after cardiac surgery. A minimum $\mathrm{StO}_{2}<75 \%$ predicted an impaired lactate clearance much better than cardiac index, mixed venous oxygen saturation or mean arterial pressure. During the observation period markers of myocardial damage increased significantly only in the subgroup with a minimum $\mathrm{StO}_{2}<75 \%$.

Cardiac surgery with or without cardiopulmonary bypass induces disturbed fluid balance and cardiac output $[16,17]$, as it was demonstrated in this observational study with reduced $\mathrm{S}_{\mathrm{v}} \mathrm{O}_{2}$ after surgery as well as by an increased lactate concentration and base deficit. Clinical studies addressing tissue perfusion and energy metabolism in the perioperative period using microdialysis of the deltoid muscle were contradictory regarding differences between off-pump and on-pump surgery $[18,19]$. In our study, a subgroup analysis demonstrated no differences between off-pump and on-pump surgery for tissue oxygenation. Fluid resuscitation as well as positive inotropic and vasoactive drug therapy are recommended to achieve early recovery resulting in sufficient tissue perfusion and oxygen metabolism as main therapeutic goals [1]. Today therapy is managed according to global parameters of haemodynamics and metabolism including cardiac output, $\mathrm{S}_{\mathrm{v}} \mathrm{O}_{2} / \mathrm{S}_{\mathrm{cv}} \mathrm{O}_{2}$, blood pressure, diuresis and lactate concentration [20,21].

Near-infrared spectroscopy of the thenar muscle, which is monitoring peripheral tissue oxygenation, might allow the more direct observation of tissue perfusion and oxygen delivery after cardiac surgery. A recent observational study using orthogonal polarization spectral imaging for the intermittent qualitative analysis of sublingual microcirculation showed that cardiac surgery is followed by sustained microcirculatory alterations that were correlating with peak lactate levels [22]. Accordingly, in our study $\mathrm{StO}_{2}$ values decreased after surgery as an indicator of impaired tissue oxygen saturation with a consecutive increase of lactate concentration and disturbed acid-base balance. Although initial normal $\mathrm{StO}_{2}$ values were accompanied by a mean $\mathrm{P}_{\mathrm{a}} \mathrm{O}_{2}>350 \mathrm{mmHg}$ with a mean $\mathrm{FiO}_{2}$ of $0.9-1.0$ at $\mathrm{T}-1$ and $\mathrm{T} 0$, a low $\mathrm{S}_{\mathrm{t}} \mathrm{O}_{2}$ was also observed together with a high $\mathrm{PaO}_{2}$ at $\mathrm{T} 1$ as well as a normal $\mathrm{S}_{\mathrm{t}} \mathrm{O}_{2}$ with a $\mathrm{PaO}_{2}=103 \mathrm{mmHg}$ at $\mathrm{T} \mathrm{d} 1$. Ikossi et al. already demonstrated in a prospective 


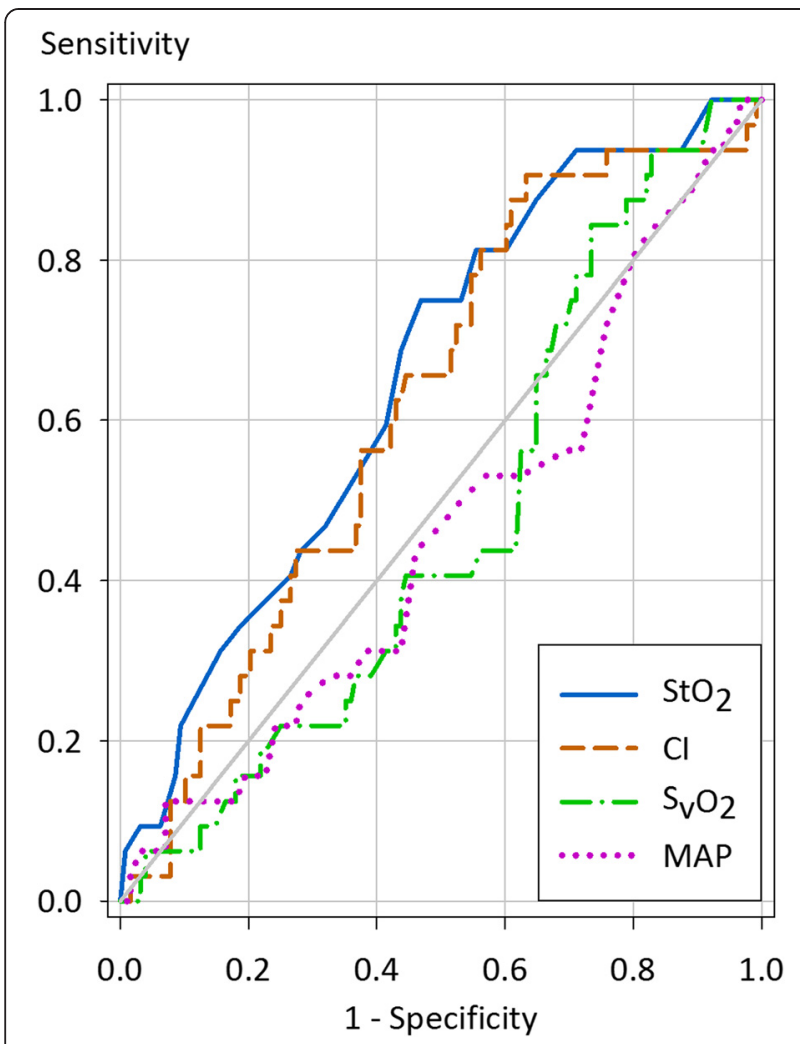

Fig. 1 ROC curve of $\mathrm{StO}_{2}$, cardiac index, $\mathrm{S}_{\mathrm{v}} \mathrm{O}_{2}$ and mean arterial pressure versus lactate clearance. Measured values from T 0 to T d1 were compared with a lactate clearance of $<10 \%$ and $\geq 10 \%$ at $T$ d1. The area under the curve is 0.65 for $\mathrm{StO}_{2}(95 \% \mathrm{Cl} 0.55-0.75 ; p$ $<0.01), 0.62$ for cardiac index (95\% Cl 0.51-0.72; $p<0.05), 0.47$ for $\mathrm{S}_{\mathrm{V}} \mathrm{O}_{2}(95 \% \mathrm{Cl} 0.37-0.58 ; p=0.63)$ and 0.46 for mean arterial pressure (95\% Cl 0.35-0.58; $p=0.51$ )

trauma study, that $\mathrm{S}_{\mathrm{t}} \mathrm{O}_{2}$ did not correlate with $\mathrm{PaO}_{2}$ [14]. This data seem to exclude an influence of very high arterial partial oxygen pressure on $\mathrm{S}_{\mathrm{t}} \mathrm{O}_{2}$.

Although recovery of $\mathrm{StO}_{2}$ occurred at day 1, increased lactate concentration and base deficit persisted probably due to delayed metabolism/wash-out of accumulated acid metabolites. In a recent editorial Vincent described how lactate concentration represents the balance between lactate production and clearance [23]. This is a quite complex process including increased lactate production, lactate release from the cells and transfer of lactate between different tissues and cells as well as diminished clearance [24]. A prospective study with 23 patients demonstrated also a reduced $\mathrm{StO}_{2}$ after cardiac surgery, but $\mathrm{StO}_{2}$ did not recover until 18-22 h after surgery [9]. Different in house standards for postoperative management may be responsible for the different recovery of tissue oxygenation after $24 \mathrm{~h}$. Continuous measurement of buccal tissue oxygen saturation with a non-invasive, visible-light optical diffusion oximeter could be an

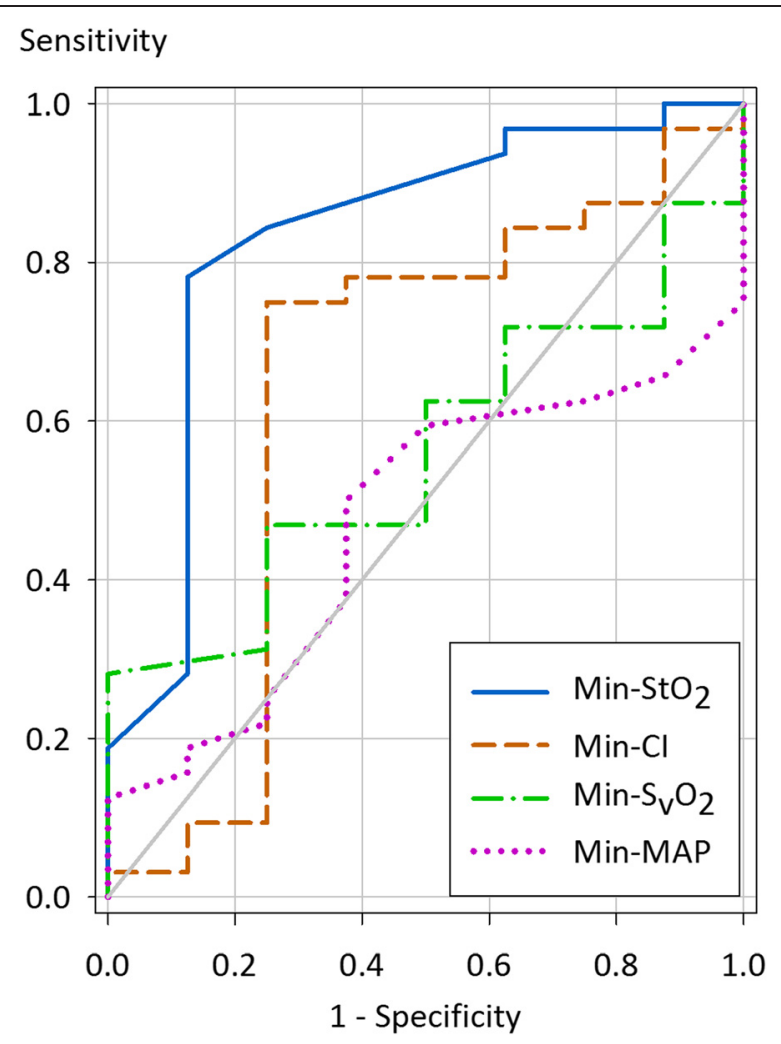

Fig. 2 ROC curve of minimum $\mathrm{StO}_{2}$, cardiac index, $\mathrm{S}_{\mathrm{v}} \mathrm{O}_{2}$ and mean arterial pressure versus lactate clearance. Minimum values of $\mathrm{StO}_{2}$ (Min- $\mathrm{StO}_{2}$ ), cardiac index (Min- $\left.\mathrm{Cl}\right), \mathrm{S}_{\mathrm{v}} \mathrm{O}_{2}\left(\mathrm{Min}-\mathrm{S}_{\mathrm{v}} \mathrm{O}_{2}\right)$ and mean arterial pressure (Min-MAP) from $\mathrm{T} 0$ to $\mathrm{T} d 1$ were compared with a lactate clearance of $<10 \%$ and $\geq 10 \%$ at $\mathrm{T} d 1$. The area under the curve is 0.83 for $\mathrm{StO}_{2}(95 \% \mathrm{Cl} 0.65-1.02 ; p<0.01), 0.64$ for cardiac index (95\% Cl 0.37-0.91; $p=0.22), 0.56$ for $\mathrm{S}_{\mathrm{v}} \mathrm{O}_{2}(95 \% \mathrm{Cl} 0.36-0.75 ; p=$ $0.61)$ and 0.47 for mean arterial pressure (95\% Cl $0.27-0.67 ; p=0.80)$

alternative method [25]. An actual observational study demonstrated a correlation of buccal $\mathrm{StO}_{2}$ and $\mathrm{S}_{\mathrm{cv}} \mathrm{O}_{2}$ in 13 children with congenital cyanotic heart disease undergoing a cardiac surgical procedure [26].

Recently, the time course of lactate concentration has been established to monitor global tissue hypoxia during severe sepsis and septic shock and found to be correlated with mortality [15]. Retrospective data suggest, that outcome after cardiac surgery is also correlating with absolute values and trend of lactate concentration [3]. In a prospective observational study with 325 unselected patients early hyperlactatemia immediately after cardiac surgery correlated with morbidity and mortality, probably as a result of intraoperative tissue hypoxia. In contrast, development of hyperlactatemia during ICU stay correlated with epinephrine dose and hyperglycaemia and was inferior with regard to the prediction of outcome [2]. When Pölönen et al. used a goal-oriented algorithm after cardiac surgery to maintain a $\mathrm{S}_{\mathrm{v}} \mathrm{O}_{2}>70 \%$ and a lactate concentration $\leq 2.0 \mathrm{mmol} \mathrm{l}^{-1}$, morbidity at hospital 
Table 3 Uni- and multivariate analysis of parameters associated with lactate clearance at day 1

\begin{tabular}{|c|c|c|c|c|c|c|c|c|}
\hline \multirow[b]{2}{*}{ Factor } & \multicolumn{4}{|c|}{ Univariate analysis } & \multicolumn{4}{|c|}{ Multivariate analysis } \\
\hline & Coefficient & $95 \%$ Confidence Interval & $r$ & $P$ & Coefficient & $95 \%$ Confidence Interval & $r$ & $P$ \\
\hline Minimum $\mathrm{StO}_{2}$ & 0.065 & $0.024-0.105$ & 0.46 & $<0.01$ & 0.053 & $0.013-0.094$ & 0.46 & $<0.05$ \\
\hline Minimum cardiac index & 0.851 & $0.208-1.494$ & 0.40 & $<0.05$ & 0.637 & $0.020-1.254$ & 0.40 & $<0.05$ \\
\hline Minimum $\mathrm{S}_{\mathrm{v}} \mathrm{O}_{2}$ & 0.014 & $-0.015-0.044$ & 0.16 & n. s. & & & & \\
\hline Minimum mean arterial pressure & -0.004 & $-0.039-0.030$ & -0.04 & n. s. & & & & \\
\hline Overall & & & & & & & 0.55 & $<0.01$ \\
\hline
\end{tabular}

Minimum values of $\mathrm{StO}_{2}$, cardiac index, $\mathrm{SvO}_{2}$ and mean arterial pressure calculated from values at T0, $\mathrm{T} 1, \mathrm{~T} 4$ and $\mathrm{Td} 1$

discharge and length of hospital stay were significantly reduced compared to standard therapy [27].

However, the analysis of the kinetics of lactate production and metabolism precludes real-time observation of sufficient tissue perfusion and requires intermittent blood withdrawals. In contrast, near-infrared spectroscopy is a non-invasive technique that bears the potential to measure directly and continuously the adequacy of tissue oxygenation, as demonstrated in this study. In fact, in our ROC-analysis, a minimum $\mathrm{StO}_{2}<75 \%$ showed the highest predictive value for an impaired lactate clearance at day 1. This threshold is in accordance with the available literature. In trauma patients, a minimum $\mathrm{StO}_{2}$ below $75 \%$ correlated with the incidence of postoperative organ dysfunction [6], and mortality of septic shock was associated with a $\mathrm{StO}_{2}$ below 78 \% after

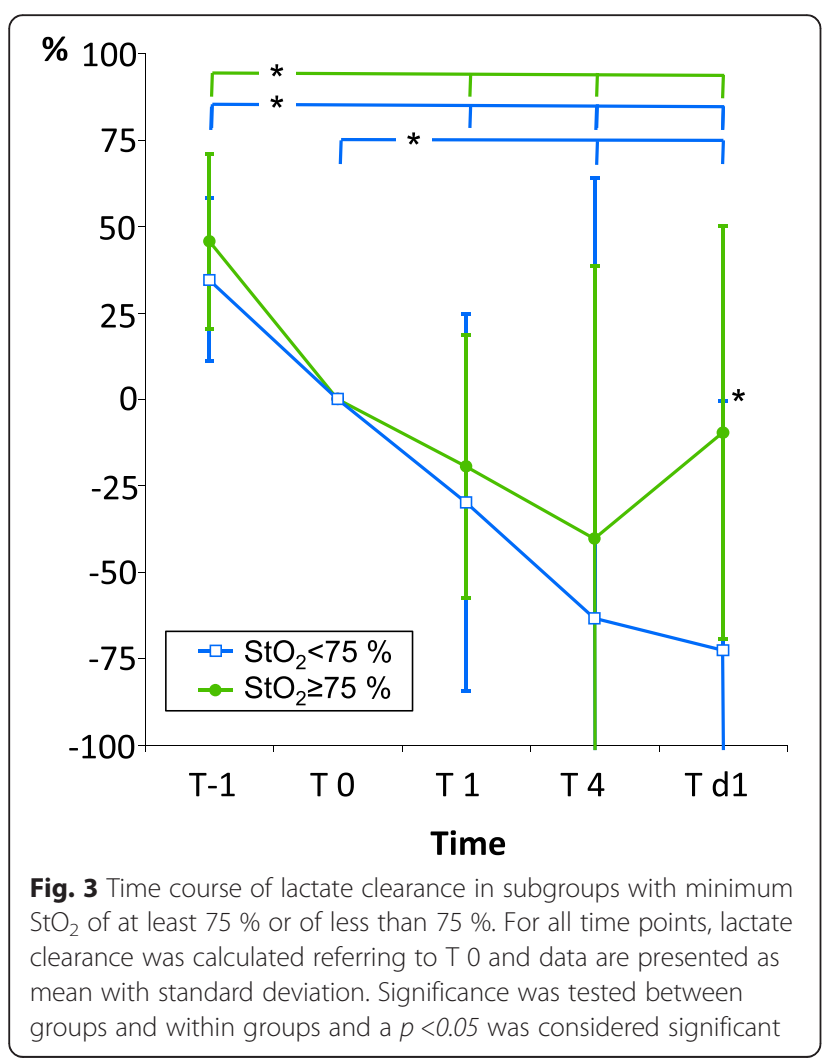

initial resuscitation [7]. Of note, in our study, minimum values of $\mathrm{StO}_{2}$ were observed already 1 and 4 h postoperatively. This further highlights the utility of $\mathrm{StO}_{2}$ as an early indicator for the later development of a disturbed lactate clearance.

Minimum cardiac output correlated also with lactate clearance and could be an alternative approach, but represents an invasive monitoring technique. Mean arterial pressure and $\mathrm{S}_{\mathrm{v}} \mathrm{O}_{2}$, which is routinely approximated by $\mathrm{S}_{\mathrm{cv}} \mathrm{O}_{2}$ in clinical practice, did not correlate with lactate clearance and demonstrated the limited value of basic monitoring to estimate lactate clearance. Our study demonstrates that $\mathrm{StO}_{2}$ combines the advantage of a non-invasive monitoring technique and the possibility to predict reduced lactate clearance.

Interestingly, only the subgroup of patients with a minimum $\mathrm{StO}_{2}<75$ \% demonstrated further increasing markers of myocardial injury from ICU admission to day 1. However, this finding was not associated with a deterioration of clinical outcome as assessed by the SOFAscore and length of stay. This is in contrast to another observational study in which decreases in $\mathrm{StO}_{2}$ were significantly associated with postoperative morbidity at

Table 4 Marker of muscle and myocardial damage

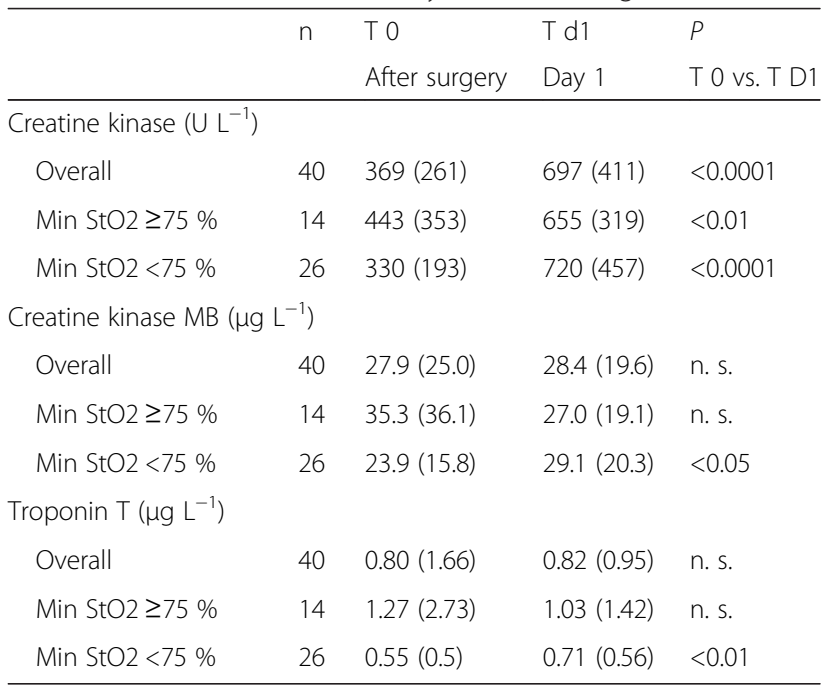

Data is presented as mean (SD) for all patients and for subgroups with minimum $\mathrm{StO}_{2}$ of at least $75 \%$ or of less than $75 \%$ at T 0 and $\mathrm{T} d 1$ 
Table 5 Intraoperative and outcome data

\begin{tabular}{|c|c|c|c|c|}
\hline & Overall & $\begin{array}{l}\text { Min StO2 } \\
\geq 75 \% \\
\end{array}$ & $\begin{array}{l}\text { Min StO2 } \\
<75 \% \\
\end{array}$ & $\begin{array}{l}P \text { between } \\
\text { subgroups }\end{array}$ \\
\hline Number (n) & 40 & 14 & 26 & \\
\hline EURO-Score (value) & $6(4)$ & $7(4)$ & $6(4)$ & n. s. \\
\hline Operation with CPB (n) & 33 & 13 & 20 & n. s. \\
\hline Duration of surgery (min) & $219(71)$ & $234(76)$ & $208(56)$ & n. s. \\
\hline Duration of CPB (min) & $133(56)$ & $127(35)$ & $137(63)$ & n. s. \\
\hline $\begin{array}{l}\text { Length of aortic } \\
\text { cross clamp (min) }\end{array}$ & $81(39)$ & $78(29)$ & $82(43)$ & n. s. \\
\hline SOFA Score T d1 (value) & $4(2)$ & $4(3)$ & $3(2)$ & n. s. \\
\hline $\begin{array}{l}\text { Duration of mechanical } \\
\text { ventilation (h) }\end{array}$ & $21(35)$ & $13(8)$ & $28(45)$ & n. s. \\
\hline Length of ICU stay (h) & $107(311)$ & 30 (29) & 161 (383) & n. s. \\
\hline
\end{tabular}

Data is presented as mean (SD) for all patients and for subgroups with minimum $\mathrm{StO}_{2}$ of at least $75 \%$ or of less than $75 \%$. Significance was tested between subgroups, but was not significant (n. s.)

day 3 and 15 according to the Post-Operative Morbidity Survey [10]. These differences may be attributed to the small number of patients included in our study that prevents reliable information about a possible correlation of minimum $\mathrm{StO}_{2}$ and outcome. A limitation of the presented study is the observational design with a limited patient number, but the presented results could be used to develop a goal directed therapy including $\mathrm{StO}_{2}$ and test this concept in a prospective clinical trial.

\section{Conclusions}

In the present study, $\mathrm{StO}_{2}$ was a non-invasive measurement of tissue oxygenation. A $\mathrm{StO}_{2}$ below a critical threshold of $75 \%$ in the early postoperative recovery period was a predictor of a decreased lactate clearance at day 1 after surgery and superior to mean arterial pressure, $\mathrm{S}_{\mathrm{v}} \mathrm{O}_{2}$ and even cardiac index. Our data suggest that a $\mathrm{StO}_{2}$ below $75 \%$ could be used as an early indicator of persistently increased lactate concentration, which is a recommended marker of tissue perfusion and oxygen metabolism [1]. Further studies are warranted that specifically address the efficacy of a goal-directed therapy based on $\mathrm{StO}_{2}$ monitoring to reduce organ dysfunction and morbidity after cardiac surgery.

\footnotetext{
Abbreviations

AUC: area under the curve; Cl: cardiac index; CVP: central venous pressure $\mathrm{FiO}_{2}$ : fraction of inspired oxygen; ICU: Intensive Care Unit; MAP: mean arterial pressure; MPAP: mean pulmonary artery pressure; NIRS: near infrared spectoscropy; PAC: pulmonary artery catheter; $\mathrm{P}_{\mathrm{a}} \mathrm{O}_{2}$ : arterial partial oxygen pressure; PCWP: pulmonary capillary wedge pressure; $\mathrm{ROC}$ : receiver operating characteristic; $\mathrm{S}_{\mathrm{a}} \mathrm{O}_{2}$ : arterial oxygen saturation; $\mathrm{S}_{\mathrm{Cv}} \mathrm{O}_{2}$ : central venous oxygen saturation; $\mathrm{SD}$ : standard deviation; $\mathrm{StO}_{2}$ : tissue oxygen saturation; $\mathrm{S}_{\mathrm{v}} \mathrm{O}_{2}$ : mixed venous oxygen saturation; THI: total haemoglobin index.
}

\section{Competing interests}

The authors state, that they have no conflicts of interest.

\section{Authors' contributions}

R. Kopp conceived the study, performed the study, analysed the data including statistics and drafted the article. K. Dommann, G. Schaelte and O. Grottke performed the study including the data collection. J. Spillner and R. Rossaint participated in data analysis and manuscript preparation. G. Marx contributed to the concept of the study and writing the manuscript. All authors read and approved the final manuscript.

\section{Acknowledgments}

No grants were received for this study.

\section{Author details \\ ${ }^{1}$ Department of Intensive Care, University Hospital RWTH Aachen, RWTH Aachen University, Pauwelsstr. 30, 52074 Aachen, Germany. ${ }^{2}$ Department of Anaesthesiology, University Hospital RWTH Aachen, RWTH Aachen University, Pauwelsstr. 30, 52074 Aachen, Germany. ${ }^{3}$ Department of Thoracic and Cardiovascular Surgery, University Hospital RWTH Aachen, RWTH Aachen University, Pauwelsstr. 30, 52074 Aachen, Germany. ${ }^{4}$ Department of Anaesthesiology, University Hospitals Leuven, Herestraat 49, 3000 Leuven, Belgium. ${ }^{5}$ Department of Cardiovascular Sciences, Katholieke Universiteit Leuven, Herestraat 49, 3000 Leuven, Belgium.}

Received: 24 July 2015 Accepted: 24 October 2015

Published online: 30 October 2015

\section{References}

1. Carl M, Alms A, Braun J, Dongas A, Erb J, Goetz A, et al. S3 guidelines for intensive care in cardiac surgery patients: hemodynamic monitoring and cardiocirculary system. Ger Med Sci. 2010;8:Doc12.

2. Maillet JM, Le Besnerais $P$, Cantoni M, Nataf $P$, Ruffenach $A$, Lessana A, et al. Frequency, risk factors, and outcome of hyperlactatemia after cardiac surgery. Chest. 2003;123(5):1361-6.

3. Lindsay AJ, Xu M, Sessler DI, Blackstone EH, Bashour CA. Lactate clearance time and concentration linked to morbidity and death in cardiac surgical patients. Ann Thorac Surg. 2013;95(2):486-92.

4. Myers DE, Anderson LD, Seifert RP, Ortner JP, Cooper CE, Beilman GJ, et al. Noninvasive method for measuring local hemoglobin oxygen saturation in tissue using wide gap second derivative near-infrared spectroscopy. J Biomed Opt. 2005;10(3):034017.

5. Creteur J. Muscle StO2 in critically ill patients. Curr Opin Crit Care. 2008;14(3):361-6.

6. Cohn SM, Nathens AB, Moore FA, Rhee P, Puyana JC, Moore EE, et al. Tissue oxygen saturation predicts the development of organ dysfunction during traumatic shock resuscitation. J Trauma. 2007;62(1):44-54.

7. Leone M, Blidi S, Antonini F, Meyssignac B, Bordon S, Garcin F, et al. Oxygen tissue saturation is lower in nonsurvivors than in survivors after early resuscitation of septic shock. Anesthesiology. 2009;111(2):366-71.

8. Abdelmalak BB, Cata JP, Bonilla A, You J, Kopyeva T, Vogel JD, et al. Intraoperative tissue oxygenation and postoperative outcomes after major non-cardiac surgery: an observational study. Br J Anaesth. 2013;110(2):241-9.

9. Uilkema RJ, Groeneveld AB. Correlates of thenar near-infrared spectroscopyderived tissue $\mathrm{O} 2$ saturation after cardiac surgery. Interact Cardiovasc Thorac Surg. 2007;6(3):265-9.

10. Sanders J, Toor IS, Yurik TM, Keogh BE, Mythen M, Montgomery HE. Tissue oxygen saturation and outcome after cardiac surgery. Am J Crit Care. 2011;20(2):138-45.

11. von Elm E, Altman DG, Egger M, Pocock SJ, Gotzsche PC, Vandenbroucke $J$, et al. The Strengthening the Reporting of Observational Studies in Epidemiology (STROBE) statement: guidelines for reporting observational studies. Lancet. 2007;370(9596):1453-7.

12. De Blasi RA, Palmisani S, Alampi D, Mercieri M, Romano R, Collini S, et al. Microvascular dysfunction and skeletal muscle oxygenation assessed by phase-modulation near-infrared spectroscopy in patients with septic shock. Intensive Care Med. 2005;31(12):1661-8.

13. Hogan CJ, Hess ML, Ward KR, Gennings C. The utility of microvascular perfusion assessment in heart failure: a pilot study. J Card Fail. 2005;11(9):713-9.

14. Ikossi DG, Knudson MM, Morabito DJ, Cohen MJ, Wan JJ, Khaw L, et al. Continuous muscle tissue oxygenation in critically injured patients: a prospective observational study. J Trauma. 2006;61(4):780-8. discussion 788-790. 
15. Nguyen HB, Rivers EP, Knoblich BP, Jacobsen G, Muzzin A, Ressler JA, et al. Early lactate clearance is associated with improved outcome in severe sepsis and septic shock. Crit Care Med. 2004;32(8):1637-42.

16. Roberts AJ, Spies SM, Sanders JH, Moran JM, Wilkinson CJ, Lichtenthal PR, et al. Serial assessment of left ventricular performance following coronary artery bypass grafting. Early postoperative results with myocardial protection afforded by multidose hypothermic potassium crystalloid cardioplegia. J Thorac Cardiovasc Surg. 1981;81(1):69-84.

17. Tschaikowsky K, Neddermeyer U, Pscheidl E, von der Emde J. Changes in circulating blood volume after cardiac surgery measured by a novel method using hydroxyethyl starch. Crit Care Med. 2000;28(2):336-41.

18. Pojar M, Mand'ak J, Cibicek N, Lonsky V, Dominik J, Palicka V, et al. Peripheral tissue metabolism during off-pump versus on-pump coronary artery bypass graft surgery: the microdialysis study. Eur J Cardiothorac Surg. 2008;33(5):899-905

19. Cossu AP, Suelzu S, Piu P, Orecchioni M, Bazzu G, Padua G, et al. Do on- and off-pump coronary bypass surgery differently affect perioperative peripheral tissue metabolism? Minerva Anestesiol. 2012;78(1):26-33.

20. Kastrup M, Markewitz A, Spies C, Carl M, Erb J, Grosse J, et al. Current practice of hemodynamic monitoring and vasopressor and inotropic therapy in post-operative cardiac surgery patients in Germany: results from a postal survey. Acta Anaesthesiol Scand. 2007;51(3):347-58.

21. Mebazaa A, Pitsis AA, Rudiger A, Toller W, Longrois D, Ricksten SE, et al. Clinical review: practical recommendations on the management of perioperative heart failure in cardiac surgery. Crit Care. 2010;14(2):201.

22. De Backer D, Dubois MJ, Schmartz D, Koch M, Ducart A, Barvais L, et al. Microcirculatory alterations in cardiac surgery: effects of cardiopulmonary bypass and anesthesia. Ann Thorac Surg. 2009:88(5):1396-403.

23. Vincent $J$ L. Serial blood lactate levels reflect both lactate production and clearance. Crit Care Med. 2015:43(6), e209.

24. Vernon C, Letourneau JL. Lactic acidosis: recognition, kinetics, and associated prognosis. Crit Care Clin. 2010;26(2):255-83. table of contents.

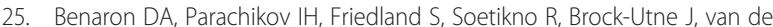
Starre PJ, et al. Continuous, noninvasive, and localized microvascular tissue oximetry using visible light spectroscopy. Anesthesiology. 2004;100(6):1469-75.

26. Yadlapati A, Grogan T, Elashoff D, Kelly RB. Correlation of a novel noninvasive tissue oxygen saturation monitor to serum central venous oxygen saturation in pediatric patients with postoperative congenital cyanotic heart disease. J Extra Corpor Technol. 2013:45(1):40-5.

27. Polonen P, Ruokonen E, Hippelainen M, Poyhonen M, Takala J. A prospective, randomized study of goal-oriented hemodynamic therapy in cardiac surgical patients. Anesth Analg. 2000;90(5):1052-9.

\section{Submit your next manuscript to BioMed Central and take full advantage of:}

- Convenient online submission

- Thorough peer review

- No space constraints or color figure charges

- Immediate publication on acceptance

- Inclusion in PubMed, CAS, Scopus and Google Scholar

- Research which is freely available for redistribution

Submit your manuscript at www.biomedcentral.com/submit 